\title{
GARCÍA JORDÁN Pilar (éd.), Para una crónica de Guarayos
}

Instituto Latinoamericano de Misionología/Itinerarios Editorial, Cochabamba, 2014

\section{Diego Villar}

\section{OpenEdition}

\section{Journals}

Édition électronique

URL : https://journals.openedition.org/jsa/14317

DOI : $10.4000 /$ jsa. 14317

ISSN : 1957-7842

\section{Éditeur}

Société des américanistes

\section{Édition imprimée}

Date de publication : 31 décembre 2015

Pagination : 315-317

ISSN : 0037-9174

\section{Référence électronique}

Diego Villar, « GARCía JoRDÁn Pilar (éd.), Para una crónica de Guarayos », Journal de la Société des

américanistes [En ligne], 101-1 et 2 | 2015, mis en ligne le 15 mars 2016, consulté le 24 février 2023.

URL : http://journals.openedition.org/jsa/14317 ; DOI : https://doi.org/10.4000/jsa.14317

Ce document a été généré automatiquement le 24 février 2023.

Tous droits réservés 


\section{GARCÍA JORDÁN Pilar (éd.), Para una crónica de Guarayos}

Instituto Latinoamericano de Misionología/Itinerarios Editorial, Cochabamba, 2014

Diego Villar

\section{RÉFÉRENCE}

GARCÍA JORDÁN Pilar (éd.), Para una crónica de Guarayos, Instituto Latinoamericano de Misionología/Itinerarios Editorial (Colección Scripta autochtona, 13), Cochabamba, 2014, 343 p., bibliogr., glossaire, index.

Completando una trilogía que incluye otras obras dedicadas a los guarayos de Bolivia (García Jordán 2006, 2009), la historiadora Pilar García Jordán recupera en este libro los diarios franciscanos de las cinco reducciones guarayas: Urubichá, Ascensión, Yotaú, Yaguarú y San Pablo. Localizados en el Archivo de Tarata, en el Archivo Histórico de la Provincia Misionera de San Antonio (Cochabamba) y en el Archivo Parroquial de Ascensión de Guarayos, los diarios narran los pormenores de la existencia franciscana entre 1927 y 1967. La información de base es apoyada por la introducción de la propia autora (p. 9-23) y por copiosas notas críticas, que contextualizan los documentos en forma exhaustiva. Se trata, en efecto, de un período fundamental para las misiones guarayas, pues su secularización data de 1939. A las desilusiones de una evangelización incompleta se suman la merma demográfica, las rencillas, las plagas que asolan los cultivos, las noticias de epidemias así como las relaciones cada vez más turbias de los misioneros con la prensa cruceña, los militares que toman el control de la región y la flagrante corrupción de las autoridades seculares. Lejos de independizarse, pues, el guarayo - «el más orgulloso de todos los salvajes » (d'Orbigny 2002 [1833], p. 1345) pasa de la tutela franciscana a un nuevo escenario en el que debe sobrevivir bajo el yugo de militares, políticos y propietarios blancos y mestizos. 
2 Los diarios compilados por Pilar García Jordán contienen los previsibles detalles de la agenda misional: qué religioso trabaja en cada poblado, los preparativos para la inminente visita del Obispo, quién celebra tal o cual misa. Pero, también, continuando una rica tradición etnográfica iniciada por religiosos católicos (Cardús 1886; Pierini 1908, 1910) y protestantes (Grubb 1924), nos ofrecen datos valiosos sobre la vida de los neófitos y sus vecinos: la onomástica mixta (Augusto Abapucu, Rosa Cuñarogui, Severo Cuñaendi, Anastasia Urañavi Antonio Mborebanchi, Filomeno Urazaipegua, Marcelina Mboirapa, etc.), los suicidios (p. 62), el alcoholismo (p. 31, 102, 115, 262, 273, 280), la persistencia de las creencias en los espíritus ânguer (p. 268), la ambivalente relación de los indígenas con el concepto de patriotismo (p.40), el servicio militar (p. 133 y 181) o la evangelización misma (p. 250). También ilustran bien los avatares de la convivencia entre los franciscanos y actores sociales tan diversos como los religiosos protestantes del Instituto Lingüístico de Verano (p. 90, 223-226), la etnóloga Wanda Hanke (caracterizada como « exploradora y científica alemana, mentirosa y ladrona [...] que se cree la salvadora de todos los indios ", p. 214), el Comité pro Santa Cruz y la Juventud Cruceñista (p. 88), el Movimiento Nacionalista Revolucionario (p. 106) e incluso eventos de la historia republicana como la Guerra del Chaco (p. 46) o la misma revolución (p. 100).

3 Los documentos también exponen las frustradas tentativas misioneras de acercamiento a los choris, los sirionós «salvajes » (p. 49, 71, 93, 174, 232, 236, 244, 266; cf. García Jordán 2011), o incluso a los grupos « bárbaros » de guarayos que se resisten a entrar a la órbita misional (p. 61, 68-69, 77-78, 171-172, 202-203, 210-212, 229-233, 241, 266, 272, 309). Con brutal honestidad los franciscanos describen hechos que muchas veces no los dejan bien parados, como las huidas de los neófitos, el desinterés indígena por la religión en tiempo festivo e incluso los frecuentes castigos corporales: "Cansado de castigar a la guaraya Tomasa Uraba por sus travesuras empléase el sistema de ponerle esposas en los pies; parece que da mejor resultado pues ni anda tanto, ni muestra tanto descaro en sus correrías diabólicas. Este sistema ha mejorado un poco los guarayos, muchachos huidores » (p. 197; cf. p. 125, 188-189, 215, 235, 247-248).

Decir que este nuevo libro de Pilar García Jordán constituye un aporte significativo para la historiografía del proyecto franciscano entre los guarayos es una obviedad. Es, asimismo, un nuevo instrumento que nos ayuda a recorrer con paciencia franciscana los recovecos más recientes del "camino sembrado de espinas y trampas » (Combès 2014, p. 389) que supone la reconstrucción de la historia indígena de las tierras bajas sudamericanas.

\section{BIBLIOGRAPHIE}

CARDÚs José

1886, Las misiones franciscanas entre los infieles de Bolivia, Librería de la Inmaculada Concepción, Barcelona. 
COMBÈs Isabelle

2014, " Guarayos, o los nombres de las rosas ", Anuario de estudios bolivianos, archivísticos y bibliográficos, 20, p. 377-394.

GARCÍA JORDÁN Pilar

2006, "Yo soy libre y no indio: soy guarayo. » Para una historia de Guarayos, 1790-1948, IFEA/PIEB/IRD/ TEIAA, Lima.

2009, Unas fotografías para dar a conocer al mundo la civilización de la república guaraya, Consejo Superior de Investigaciones Científicas, Madrid.

2011, Para una historia de los sirionó, Instituto Latinoamericano de Misionología/Itinerarios Editorial (Colección Scripta autochtona, 7), Cochabamba.

GRUBB W. Barbrooke

1924, « Mythology of the Guarayo Indians », Folklore, 35 (2), p. 184-194.

ORBIGNY Alcide (d')

2002, Viaje a la América meridional (realizado de 1826 a 1833), IFEA/Plural Editores, La Paz [1833].

PIERINI Francesco

1908, « Los guarayos de Bolivia », Anthropos, 3 (5-6), p. 875-880.

1910, « Mitología de los guarayos de Bolivia », Anthropos, 5 (3), p. 703-710.

\section{AUTEURS}

DIEGO VILLAR

Conicet, Argentina 